\title{
URGENSI REKONSTRUKSI HUKUM E-COMMERCE DI INDONESIA
}

\author{
Margaretha Rosa Anjani' ${ }^{1}$, Budi Santoso ${ }^{2}$ \\ Program Studi Magister IImu Hukum \\ Fakultas Hukum Universitas Diponegoro \\ J I. Imam Bardjo, S.H. No. 1-3, Kampus Pleburan, Semarang 50241 \\ margaretharosa@gmail.com
}

\begin{abstract}
In the digital economy era, the use of the internet as a means of electronic commerce (e-commerce) have significant experiencing development. The existence of the regulation of e-commerce in indonesia have not been comprehensively in providing legal protection against the e-commerce's subject.The issues raised in this research are about aspects of the legal arrangements for implementation of ecommerce in Malaysia and in Indonesia and about the regulation of the e-commerce that can be expected applied in Indonesia. Approach method is juridical normative legal research or doctrinal, where this legal research emphasis on review of legal documents and materials the literature relating to the fine points of the problem. In this study the author uses secondary data obtained from primary and secondary legal materials. Based on the results can be drawn the conclusion that the legal or policy setting in the field of the law of e-commerce has been basically set up and recognized in Indonesia, but the regulation are still partially of the activities of e-commerce, Indonesia did not yet have regulations as the specific ground rules and infrastructure-technical infrastructure that supports the realization of ecommerce. While Malaysia itself has to have special rules for the implementation of e-commerce. Where the law is accommodate other legislation that supports the implementation of e-commerce. Advice that can be given through the results of this research is the need for special legislation regulating ecommerce to provide protection and certainty for the partieselectronic transaction and build system dispute resolution through the Online Dispute Resolution.
\end{abstract}

\section{Keywords: Urgency; The Regulations; E-Commerce}

\begin{abstract}
ABSTRAK
Pada era ekonomi digital, penggunaan media internet sebagai sarana perdagangan secara elektronik (e-commerce) mengalami perkembangan yang signifikan . Keberadaan regulasi e-commerce di indonesia belum secara komprehensif dalam memberikan perlindungan hukuk terhadap para pelaku e-commerce.Permasalahan yang diangkat dalam penelitian ini yaitu tentang aspek pengaturan hukum bagi pelaksaan e-commerce di Malaysia dan di Indonesia dan tentang pengaturan e-commerce yang diharapkan yang dapat diterapkan di Indonesia. Metode pendekatan yang digunakanadalah yuridis normatif atau penelitian hukum doktrinal, dimana penelitian hukum ini menekankan pada penelaahan dokumen-dokumen hukum dan bahan-bahan pustaka yang berkaitan dengan pokok-pokok

\footnotetext{
${ }^{1}$ Calon Jaksa di Kejaksaaan Negeri Majene, Majene, Sulawesi Barat

2 Dosen Program Studi Magister IImu Hukum UNDIP
} 
permasalahan. Penelitian ini menggunakan data sekunder yang diperoleh dari bahan hukum primer dan sekunder. Berdasarkan hasil penelitian dapat ditarik kesimpulan bahwa kebijakan hukum di bidang ecommerce pada dasarnya telah diatur dan diakui di Indonesia, namun pengaturan tersebut masih secara parsial atau sebagian dari kegiatan e-commerce, Indonesia belum memiliki regulasi yang mengatur secara spesifik aturan-aturan dasar dan infrastruktur-infrastruktur teknis yang mendukung realisasi e-commerce. Sedangkan Malaysia telah memiliki peraturan khusus bagi pelaksanaan ecommerce. Dimana undang-undang ini mengakomodir undang-undang lainnya yang mendukung pelaksaan e-commerce. Saran yang dapat diberikan melalui hasil penelitian ini adalah diperlukannya undang-undang khusus yang mengatur e-commerce untuk memberikan perlindungan dan kepastian bagi para pihak yang bertransaksi secara elektronik dan dapat membangun sistem penyelesaian sengketa melalui Online Dispute Resolution.

\section{Kata kunci : Urgensi; Pengaturan Hukum; E-Commerce}

\section{Pendahuluan}

Abad informasi teknologi saat ini telah membawa perkembangan telematika yang sangat signifikan yaitu digunakan dan dimanfaatkan jaringan internet melalu media komputer (Suhardo, 2007). Teknologi informasi dan komunikasi telah mengubah perilaku masyarakat dan peradaban manusia secara global. Internet sendiri merupakan keseluruhan jaringan komputer yang saling terhubung menggunakan standar sistem global yaitu Transmission Control Protocol/Internet Protocol Suite (TCP/IP) sebagai protokol pertukaran paket (packet switching communication protocol) untuk melayani miliaran pengguna di seluruh dunia.

Data hasil survey pengguna internet Indonesia yang diperoleh dari Asosiasi Penyelenggara Jasa Internet Indonesia tahun 2016, tercatat bahwa pengguna internet di Indonesia sebesar 132,7 juta orang dimana pengguna terbanyak sejumlah 86.3 juta orang ada di pulau Jawa dan kedua di Sumatera (Indonesia, 2016). Sebanyak 132,7 juta pengguna internet memanfaatkan internet untuk media sosial (97.4\%), hiburan (96.8\%), berita (96.4\%), pendidikan (93.8\%), komersial (93.1\%), dan layanan publik (91.6\%) (Indonesia, 2016).

Saat ini, penggunaan media internet tidak terbatas pada pemanfaatan informasi melainkan juga digunakan sebagai sarana untuk melakukan transaksi dan beberapa perusahaan telah mulai menggunakannya yaitu perdagangan secara elektronik atau yang kita kenal sebagai electronic commerce (e-commerce).

E-commerce merupakan model bisnis modern yang non-face atau tidak menghadirkan pelaku bisnis secara fisik dan non-sign (tidak memakai tanda tangan asli). E-commerce merupakan bisnis dengan melakukan pertukaran data (data interchange) via internet dimana kedua belah pihak, yaitu orifinator dan adresser atau 
penjual dan pembeli barang dan jasa,dapat melakukan bargaining dan transaksi (Suparni, 2009). Cara ini menjanjikan akses tanpa batas, cepat dan interaktif memudahkan konsumen dalam memperoleh suatu produk sesuai keinginan tanpa harus keluar rumah. Saat ini, internet dan e-commerce telah menjadi sebuah gaya hidup baru bagi masyarakat di seluruh dunia, salah satunya Indonesia.

Dewasa ini, di negara-negara maju permasalahan mengenai e-commerce sudah menjadi sesuatu yang lumrah dan telah memiliki perangkat pengaturan hukumnya. Perkembangan transaksi online sendiri secara global mengalami pertumbuhan meningkat. Nilai transaksi bisnis ecommerce secara global telah mencapai 1,25 triliun dolar AS pada tahun 2013. Wilayah regional Asia Tenggara menjadi sebuah gambaran kesuksesan era modern. Pada 2030, 64\% kemakmuran kelas menengah akan terdapat di Asia. Perusahaan seperti Amazon dan Londonbased ASOS telah memperhitungkan Asia Tenggara seperti Singapura, Malaysia, Thailand, dan Indonesia sebagai pertumbuhan pasar tercepat di Asia (Suparman, 2015).

Perdagangan melalui sarana elektronik saat ini diatur dalam Undang-undang Nomor 11 Tahun 2008 yang telah diubah menjadi Undangundang Nomor 19 Tahun 2016 tentang Informasi dan Transaksi Elektronik, Undang-undang Nomor 7 Tahun 2014 tentang Perdagangan serta
Peraturan Pemerintah Nomor 82 Tahun 2012 Tentang Penyelenggaraan Sistem Dan Transaksi Elektronik. Aturan tersebut sifatnya masih parsial karena belum menjangkau permasalahan utama dalam penggunaan e-commerce, yaitu kontrak elektronik, pembayaran elektronik dan jaminan keamanan, penyelesaian sengketa, batas negara dan hukum yang digunakan, perlindungan konsumen, pajak dan yang terutama adalah harmonisasi sistem hukum.

Disisi lain, Pemerintah Malaysia telah melihat pertumbuhan dan perluasan teknologi informasi dan komunikasi dalam bidang perdagangan. Banyak pengusaha di Malaysia yang lebih memilih untuk menggunakan media elektronik sebagai tempat untuk menjual produk mereka, mengingat dengan memanfaatkan internet menjadi lebih efektif dan efesien. Oleh sebab itu pemerintah Malaysia mengakomodir undang-undang yang dapat menjadi payung hukum bagi pelaku perdagangan elektronik, peraturan yang mengatur tentang transaksi elektronik diatur dalam Electronic Commerce 2006, termasuk the Digital Signature Act 1997 diberlakukan secara khusus untuk menangani isuisu dan masalah-masalah yang berkaitan dengan kegiatan tersebut.

Meluasnya pemanfaatan teknologi melalui internet di segala sektor telah membawa konsekuensi tertentu, selain dari aspek teknologi sendiri, juga membutuhkan pendekatan dari segi 
hukum yang merupakan langkah preventif dan represif terhadap upaya-upaya penyalahgunaan teknologi informasi pada umumnya dan penggunaan media internet pada khususnya (Suhardo, 2007).

Urgensi perdagangan elektronik bagi Indonesia diharuskan untuk meletakkan dasar legal dan kultur bagi masyarakat Indonesia untuk masuk dan menjadi pelaku dalam memanfaatkan kecanggihan dibidang teknologi informasi dan mengantisipasi perkembangan teknologi dengan suatu payung hukum yang mempunyai kepastian hukum yang kuat.

\section{Metode Penelitian}

Metode penelitian pada dasarnya merupakan suatu cara yang harus ditempuh agar dapat menemukan jawaban yang benar atau menemukan kebenaran untuk menjawab pertanyaan yang sedang atau akan dibahas.Pendekatan penelitian yang digunakan dalam penelitian ini adalah metode pendekatan yuridis normatif atau penelitian hukum doktrinal yaitu penelitian hukum yang mempergunakan sumber data sekunder dimana penelitian hukum yang menekankan pada penelaahan dokumendokumen hukum dan bahan-bahan pustaka yang berkaitan dengan pokok-pokok permasalahan (Soekanto, 2007).

\section{Pembahasan}

\section{A.Pengaturan E-Commerce Di Indonesia Dan Di Malaysia}

\section{Pengaturan E-Commerce Di Indonesia}

\subsection{Legalitas Perjanjian Elektronik Berdasar} kan Pasal 1320 Kitab Undang-Undang Hukum Perdata

Salah satu faktor yang mempengaruhi perkembangan hukum perjanjian di Indonesia adalah perkembangan di bidang perdagangan (Busro, 2009). Dalam pandangan umum, transaksi jual-beli merupakan salah satu jenisPerjanjian yang diatur dalam buku III Kitab Undang-undang Hukum Perdata (KUHPerdata) perjanjian ini termasuk salah satu perjanjian riil artinya perjanjian ini yang baru terjadi kalau barang yang menjadi pokok perjanjian telah diserahkan.

Kehadiran Internet telah memberikan kemudahan akses bagi konsumen untuk mencari barang dan jasa. Manfaat internet secara tidak langsung mempengaruhi peningkatan persaingan perdagangan dan harga yang lebih rendah dengan banyak opsi produk dan layanan serta tingkat kenyamanan berbelanja dari berbagai vendor di seluruh dunia, dari mana saja dan kapan saja. E-Commerce menjadi sarana penting untuk perekonomian negara-negara berkembang (P.Baghen \& Hassan, 2011).

Transaksi elektronik yang juga merupakan suatu transaksi jual beli tentu saja dalam 
prosesnya terdapat suatu perjanjian. Perjanjian ecommerce yang dilakukan oleh para pihaknya bukan seperti perjanjian pada umumnya, tetapi perjanjian tersebut dapat dilakukan, meskipun tanpa adanya pertemuan langsung antara kedua belah pihak, namun perjanjian antar para pihak tersebut dilakukan secara elektronik. Transaksi elektronik dapat dituangkan dalam sebuah kontrak elektronik, maka kontrak tersebut mengikat para pihak (Kaligis, 2012). Kontrak elekronik merupakan wujud otomatisasi pembentukan kontrak dan berlakunya dalam perjanjian transaksi online. Penerapan kontrak elektronik bertujuan untuk menciptakan efisiensi biaya, waktu, dan masalah kompleksitas yang terjadi dalam kontrak secara fisik.

Dalam kaitannya suatu perjanjian yang terjadi dalam transaksi e-commerce tetap mengacu pada pasal 1320 KUHPerdata. Pasal 1320 KUHPerdata mengatur agar suatu perjanjian oleh hukum dianggap sah sehingga mengikat kedua belah pihak, maka perjanjian tersebut harus memenuhi syarat-syarat sahnya perjanjian. Syarat sahnya perjanjian meliputi syarat subyektif dan syarat obyektif: (Subekti, 2001)

Syarat subyektif:

1. sepakat mereka mengikatkan dirinya

2. cakap untuk membuat suatu perjanjian

Syarat obyektif:

3. Mengenai suatu hal tertentu
4. Suatu sebab yang halal

Perihal kontrak elektronik telah tercantum pada pasal 18, kontrak perdagangan elektronik sah ketika terdapat kesepakatan para pihak. Transaksi Elektronik yang dituangkan ke dalam Kontrak Elektronik mengikat para pihak. Kontrak Perdagangan Elektronik paling sedikit harus memuat identitas para pihak, spesifikasi barang dan atau Jasa yang disepakati, legalitas barang dan atau jasa, nilai transaksi perdagangan, persyaratan dan jangka waktu pembayaran, prosedur operasional pengiriman barang dan atau jasa, dan prosedur pengembalian barang dan atau jika terjadi ketidaksesuaian. Kontrak Perdagangan Elektronik dapat menggunakan tanda tangan elektronik dan harus dibuat dalam bahasa Indonesia.

\subsection{Eksistensi Dan Pengakuan Sarana \\ Elektronik/ Dokumen Elektronik Di Indonesia}

Undang-Undang No. 11 Tahun 2008 yang telah dirubah dalam Undang-Undang Nomor 19 Tahun 2016 tentang Informasi dan Transaksi Elektronik (UU ITE) merupakan cyber law yang pertama dimiliki Indonesia. Perdagangan Elektronik juga didukung dengan Undang-undang Nomor 7 Tahun 2014 tentang Perdagangan. Pengaturan e-commerce dalam undang-undang ini ditujukan agar dapat memberikan kepastian dan kesepahaman mengenai apa yang dimaksud dengan e-commerce dan memberikan 
perlindungan, kepastian kepada pelaku usaha elektronik, penyelenggara e-commerce, dan konsumen dalam melakukan kegiatan perdagangan melalui sistem elektronik.

Keabsahan hubungan kontraktual dalamkegiatan e-commerce tetap mengacu pada persyaratan material untuk tidak memuat klausul yang menyebabkan kerugian bagi para pihak. Meskipun secara teknis transaksi dilakukan melalui jaringan internet dimana kontrak terjadi akibat bertemunya syarat dan kondisi dalam suatu penawaran secara elektronik dengan kondisi /persetujuan secara elektronik

Berdasarkan ketentuan pasal 65 Undangundang Nomor 7 Tahun 2014 tentang Perdagangan diatur bahwa setiap pelaku usaha yang memperdagangkan Barang dan atau Jasa dengan menggunakan sistem elektronik wajib menyediakan data dan atau informasi secara lengkap dan benar.

Disisi lain, keberadaan Obyek dalam transaksi elektronik tidak mungkin dapat diresepsi secara sempurna secara elektronik, sehingga konsumen harus diberikan kesempatan untuk dapat membatalkan perjanjian jika obyek tidak sesuai yang diharapkan dan/atau diperjanjikan. Calon pembeli/pengguna harus diberikan kesempatan untuk melakukan pembatalan tersebut dengan konsekuensi pengembalian biaya administratif.
Berkaitan dengan akuntabilitas dan tingkat keterpercayaan dalam menentukan bobot pembuktian atas suatu kontrak elektronik, maka diperlukan perhatian terhadap reliabilitas keamanan sistem elektronik tersebut, baik dalam konteks sistem informasi maupun sistem komunikasi yang digunakan (Makarim, 2014). Ketentuan Pasal 5 UU ITE menyatakan bahwa Informasi Elektronik dapat menjadi suatu alat bukti yang sah, namun sejauh mana informasi tersebut memiliki sifat kekuatan yang mengikat dalam pembuktian ditentukan oleh aspek reliabilitasnya. Konsekuensinya adalah kehadiran suatu informasi elektronik sebagai alat bukti tidak dapat dikarenakan berwujud dalam sistem elektronik, namun hal yang harus diperhatikan ialah kesetaraan fungsionalnya (functional equivalent approach) seperti kelayakan bukti tulisan di atas kertas. Hal itu dapat melihat kepada sistem keamanan atau keautentikannya (e-authentication) yang salah satunya adalah penggunaan teknologi Tanda Tangan Elektronik.sehingga dapat dinyatakan bahwa , sistem keautentikan secara elektronik adalah ekuivalen dengan penggunaan tanda tangan elektronik.

\subsection{Pajak E-Commerce}

Berdasarkan Surat Edaran Direktur Jenderal Pajak Nomor SE/62/PJ/2013 tentang Penegasan Ketentuan Perpajakan Atas Transaksi e-Commerce. Terbitnya Paket Kebijakan Ekonomi 
Jilid XIV oleh pemerintah yang di antaranya memuat kebijakan pajak e-commerce, membagi transaksi e-commerce ke dalam 4 model transaksi e-commerce, yaitu Online Marketplace, Classified Ads, Daily Deals, dan Online Retail.

a) Online Marketplace adalah kegiatan menyediakan tempat kegiatan usaha berupa Toko Internet seperti Mal tetapi menggunakan sarana Internet sebagai tempat Merchant menawarkan barang dan/atau jasa.

b) Classified Ads adalah kegiatan menyediakan tempat dan/atau waktu untuk memajang content (teks, grafik, video penjelasan, informasi, dan lain-lain) barang dan/atau jasa bagi Pengiklan untuk memasang iklan yang ditujukan kepada Pengguna Iklan melalui situs yang disediakan oleh Penyelenggara Classified Ads.

c) Daily Deals merupakan kegiatan menyediakan tempat kegiatan usaha berupa situs Daily Deals sebagai tempat Daily Deals Merchant menjual barang dan/atau jasa kepada Pembeli dengan menggunakan Voucher sebagai sarana pembayaran.

d) Online Retail adalah kegiatan menjual barang dan atau jasa yang dilakukan oleh Penyelenggara Online Retail kepada Pembeli di situs Online Retail.

\subsection{Penyelesaian Sengketa E-commerce}

Pada diri debitur terdapat suatu kewajiban untuk memenuhi prestasi dan bila prestasi itu tidak dilaksanakan maka debitur dikatakan telah melakukan tindakan yang dinamakan ingkar janji atau wanprestasi.

Wanprestasi membawa akibat yang merugikan bagi kreditur, oleh karena itu sejak saat itu debitur berkewajiban mengganti kerugian yang tibul dan kreditur dapat meminta:

a) Pengganti kerugian

b) Benda yang dijadikan obyek perikatan sejak saat tidak dipenuhinya kewajiban menjadi tanggung jawab dari debitur

c) Bila perikatan timbul perjanjian yang timbal balik, kreditur dapat meminta pembatalan atau pemutusan perjanjian.

Apabila atas perjanjian yang disepakati terjadi pelanggaran, maka dapat diajukan gugatan wanprestasi, karena ada hubungan kontraktual antara pihak yang menimbulkan kerugian dan pihak yang menderita kerugian.Tata cara mengajukan gugatan ini dilakukan sesuai dengan peraturan perundang-undangan yang berlaku, yaitu HIR (Kaligis, 2012).

Dalam melindungi konsumen pada transaksi e-commerce, UU ITE membuka kemungkinan bagi masyarakat untuk mengajukan upaya hukum berupa gugatan perwakilan (class action) terhadap pihak-pihak yang menyelenggarakan sistem elektronik dan/atau 
menggunakan Teknologi Informasi yang berakibat merugikan masyarakat. Gugatan class action inilah yang kerap dilakukan oleh masyarakat terhadap setiap penyelenggara sistem elektronik (Kaligis, 2012).

Selain penggunaan forum pengadilan UU ITE membuka kemungkinan dilakukannya penyelesaian sengketa alternatif (alternative dispute resolution) untuk menyelesaikan sengketa tersebut. Penyelesaian sengketa menggunakan alternative dispute resolution melalui arbitrase.

\subsection{Kekuatan Pembuktian Terhadap Informasi Elektronik, Dokumentasi Elektronik, Dan Tanda Tangan Digital}

Pembuktian adalah proses untuk membuktikan suatu kasus yang disertai dengan fakta-fakta yang dapat dianalisis dari segi hukum untuk memberikan keyakinan hakim dalam pengambilan keputusan (Barkatullah \& Prasetyo, 2009).

Menurut pasal 1 angka 1 UU ITE Informasi Elektronik dipahami sebagai satu atau sekumpulan data elektronik, termasuk tetapi tidak terbatas pada tulisan, suara, gambar, peta, rancangan, foto, electronic data interchange (EDI), surat elektronik (electronic mail), telegram, teleks, telecopy atau sejenisnya, huruf, tanda, angka, Kode Akses, simbol, atau perforasi yang telah diolah yang memiliki arti atau dapat dipahami oleh orang yang mampu memahaminya. Sedangkan pengertian Dokumen Elektronik terdapat dalam pasal 1 angka 4 yang dipahami sebagai sebagai setiap Informasi Elektronik yang dibuat, diteruskan, dikirimkan, diterima, atau disimpan dalam bentuk analog, digital, elektromagnetik, optikal, atau sejenisnya, yang dapat dilihat, ditampilkan, dan/atau didengar melalui Komputer atau Sistem Elektronik, termasuk tetapi tidak terbatas pada tulisan, suara, gambar, peta, rancangan, foto atau sejenisnya, huruf, tanda, angka, Kode Akses, simbol atau perforasi yang memiliki makna atau arti atau dapat dipahami oleh orang yang mampu memahaminya. Informasi atau dokumen elektronik dapat digunakan sebagai suatu alat bukti. Informasi atau dokumen elektronik memiliki nilai kekuatan hukum yang sama dengan akta otentik. UU ITE pasal 1 angka 12 memberikan pengertian terhadap Tanda Tangan Elektronik yaitu tanda tangan yang terdiri atas Informasi Elektronik yangdilekatkan, terasosiasi atau terkait dengan Informasi Elektronik lainnya yang digunakan sebagai alat verifikasi dan autentikasi.

Perihal memberikan dasar hukum mengenai kekuatan hukum alat bukti elektronik, telah diatur dalam Pasal 5 Undang-undang Nomor 11 Tahun 2008 dan penjelasan pasal 5 Undangundang Nomor 19 Tahun 2016. Pasal 5 Undangundang Nomor 11 Tahun 2008, mengatur bahwa: 
1) Informasi Elektronik dan/atau Dokumen dan hal yang berkaitan dengan perbuatan hukum Elektronik dan/atau hasil cetaknya yang dilakukan melalui Sistem Elektronik. merupakan alat bukti hukum yang sah. Undang-Undang ini memberikan pengakuan

2) Informasi Elektronik dan/atau Dokumen secara tegas bahwa meskipun hanya merupakan Elektronik dan/atau hasil cetaknya suatu kode, Tanda Tangan Elektronik memiliki sebagaimana dimaksud pada ayat (1) kedudukan yang sama dengan tanda tangan merupakan perluasan dari alat bukti yang manual pada umumnya yang memiliki kekuatan sah sesuai dengan Hukum Acara yang hukum dan akibat hukum. berlaku di Indonesia.

\section{Pengaturan E-Commerce Malaysia}

3) Informasi Elektronik dan/atau Dokumen Malaysia sebagai negara dengan tingkat Elektronik dinyatakan sah apabila menggunakan Sistem Elektronik sesuai dengan ketentuan yang diatur dalam Undang-undang ini.

4) Ketentuan mengenai Informasi Elektronik dan/atau Dokumen Elektronik sebagaimana dimaksud pada ayat (1) tidak berlaku untuk: (a) surat yang menurut Undang-Undang harus dibuat dalam bentuk tertulis; dan (b) surat beserta dokumennya yang menurut Undang- Undang harus dibuat dalam bentuk akta notaril atau akta yang dibuat oleh pejabat pembuat akta.

Pasal tersebut dipertegas dengan penjelasan pasal 5 Undang-undang Nomor 19 Tahun 2016, yaitu bahwa keberadaan Informasi Elektronik dan/atau Dokumen Elektronik mengikat dan diakui sebagai alat bukti yang sah untuk memberikan kepastian hukum terhadap Penyelenggaraan Sistem Elektronik dan Transaksi Elektronik, terutama dalam pembuktian penggunaan e-commerce yang tinggi karena faktor internet dan konektivitas jaringan ponsel, serta dorongan sektor publik. Malaysia melakukan penghitungan bahwa 15.3 juta pembeli online (50\% dari populasi) dan 62\% menggunakan ponsel mereka untuk berbelanja online.

E-commerce sebagai salah satu bentuk perluasan manfaat dari internet membutuhkan peraturan hukum yang mengatur sebagai alat dalam mengintegrasikan masyarakat untuk mencapai suatu keteraturan sosial. Kerangka hukum e-commerce suatu negara berperan penting dalam mengaktifkan dan memfasilitasi transaksi elektronik domestik dan luar negeri.

$$
\text { Regulasi E-Commerce di Malaysia }
$$
pertama kali disahkan pada tanggal 30 Agustus 2006 yaitu Electronic Commerce Act 2006. Peraturan ini merupakan sumber utama pengaturan e-commerce bagi sektor privat. Dilengkapi dengan Electronic Government Activities Act 2007, yang berlaku aturan serupa 
untuk sektor publik. Electronic Commerce Act tandatangan digital melalui Electronic Commerce 2006 merupakan cermin dari United Nations Electronic Communications Convention. Malaysia Act 2006 dan Digital Signature Act 1997, upaya juga memiliki undang-undang khusus untuk tanda tangan digital yaitu Digital Signature Act 1997.Dalam rangka melindungi pengguna ecommerce, Malaysia memiliki Consumer Protection Act 1999 yang telah diamandemen pada tahun 2007.Undang-undang ini bertujuan untuk melindungi konsumen terhadap berbagai kecurangan dan memberlakukan standar minimum produk dan memperluas ruang lingkup perlindungan dalam pelaksanaan transaksi perdagangan elektronik.

Selain itu, Electronic Commerce Act 2006 memuat ketentuan mengenai tanda tangan elektronik.Dalam menindaklanjuti hal tersebut, Pemerintah Malaysia mengatur sebuah regulasi khusus yang berkaitan dengan perlindungan keamanan data pribadi pada sistem transaksi elektronik dalam e-commerce yaitu Personal Data Protection Act 2010. (Palanissamy, 2013). Pengeluaran produk hukum tersebut bertujuan sebagai langkah preventif dalam memberikan perlindungan yang kuat pada pembangunan pondasi ekonomi digital di Malaysia.

Regulasi pendukung yang terlebih dahulu diterbitkan oleh Pemerintah Malaysia guna mendukung kegiatan E-commerce, berkaitan dengankonten online yaitu Communications and Multimedia Act 1998, dokumen elektronik dan perlindungan konsumen dalam e-commerce dirujuk pada Consumer Protection Act 1999 untuk melindungi kepentingan konsumen. Berikut adalah konstruksi hukum e-commerce di malaysia.

Kemunculan sejumlah peraturan terkait e-commerce tersebut, tidak terlepas dari rencana Pemerintah Malaysia yang sedang gencar dalam meningkatkan pangsa pasar atas produknya di Kawasan ASEAN. Selain itu, sejumlah regulasi diatas berfungsi sebagai alat perlindungan konsumen dengan menekankan terhadap: a). Jaminan standar kualitas barang ,b). keamanan transaksi,c).Tanggung jawab terhadap gugatan konsumen dalam lintas batas wilayah,d). Mekanisme ganti rugi e) memfasilitasi skala perdagangan yang lebih besar.

Dalam memberikan kemudahan berinvestasi pada perusahaan perdagangan online. Pemerintah Malaysia juga mengeluarkan program 8th Plan untuk memperkuat infrastruktur bidang Informatika dan Komunikasi yang terdiri dari (Palanissamy, 2013):

a) untuk memastikan informasi nasional keamanan; b) untuk membuat pusat Tanggap Darurat terkait masalah regulasi dan teknis; c) untuk memastikan tingkat keamanan internet. Terlepas dari rencana tersebut, Pemerintah Malaysia mendirikan 
lembaga pelayanan yang bekerja untuk memantau pertumbuhan teknologi informasi dan komunikasi yang bekerjasama dengan organisasi lain seperti Malaysian Institute of Microelectronic System, Perusahaan Pengembangan Multimedia serta Badan Komunikasi \& Multimedia Malaysia. Selain itu, Malaysia juga berpartisipasi dalam Kerjasama Ekonomi Asia Pasifik (APEC) untuk berkolaborasi dalam merancang undang-undang, peraturan, dan kebijakan Ecommerce. Dengan keberadaan sejumlah kebijakan dan perncanaan pembangunan di sektor IT , Malaysia diharapkan segera menjadi salah satu industri yang paling berkembang

\section{Tabel. 1.1}

\begin{tabular}{|c|c|}
\hline \multicolumn{2}{|c|}{$\begin{array}{c}\text { KONSTRUKSI HUKUM E-COMMERCE } \\
\text { MALAYSIA }\end{array}$} \\
\hline Sistem Hukum & Common Law System \\
\hline $\begin{array}{l}\text { Pengaturan } \\
\text { Hukum Jual- } \\
\text { Beli Online }\end{array}$ & $\begin{array}{l}\text { Electronic Commerce } \\
\text { Act } 2006\end{array}$ \\
\hline $\begin{array}{l}\text { Pengakuan } \\
\text { Jual-Beli Online }\end{array}$ & $\begin{array}{l}\text { Article } 6 \text { (1) "Any } \\
\text { information shall not be } \\
\text { denied legal effect, } \\
\text { validity or enforceability } \\
\text { on the ground that it is } \\
\text { wholly or partly in an } \\
\text { electronic form." }\end{array}$ \\
\hline $\begin{array}{l}\text { Acuan Hukum } \\
\text { Pembentukan } \\
\text { Pengaturan }\end{array}$ & $\begin{array}{ll}\text { UNCITRAL } & \text { Model Law } \\
\text { on } & \text { Electronic } \\
\text { Commerce } & \\
\end{array}$ \\
\hline $\begin{array}{l}\text { Substansi } \\
\text { Pengaturan }\end{array}$ & $\begin{array}{l}\text { 1. Pendahuluan } \\
\text { 2. Pengaturan } \\
\text { hukum tentang } \\
\text { pesan elektronik }\end{array}$ \\
\hline
\end{tabular}

\begin{tabular}{|c|c|}
\hline & $\begin{array}{ll}\text { 3. Pemenuhan syarat } \\
\text { hukum melalui } \\
\text { syarat elektronik } \\
\text { 4. Komunikasi pesan } \\
\text { elektronik } \\
\text { 5. Lain-lain }\end{array}$ \\
\hline $\begin{array}{l}\text { Legalitas } \\
\text { Perjanjian Jual- } \\
\text { Beli Online }\end{array}$ & $\begin{array}{l}\text { Electronic Commerce } \\
\text { Act } 2006 \text { mengatur } \\
\text { mengenai syarat sah } \\
\text { yang harus dipenuhi } \\
\text { dalam jual beli online, } \\
\text { yang terdapat dalam } \\
\text { article 8-16, yaitu: } \\
\text { 1. Harus bersifat } \\
\text { tertulis } \\
\text { 2. Adanya tanda } \\
\text { tangan } \\
\text { 3. Segel } \\
\text { 4. Saksi mata } \\
\text { 5. Dokumen harus } \\
\text { dalm bentuk asli } \\
\text { 6. Dokumen dapat } \\
\text { dipertahankan } \\
\text { 7. Memiliki salinan } \\
\text { 8. Memenuhi bentuk } \\
\text { yang ditetapkan } \\
\text { 9. Mempunyai } \\
\text { ketentuan layanan } \\
\text { dan pengiriman }\end{array}$ \\
\hline $\begin{array}{l}\text { Aspek } \\
\text { Perpajakan }\end{array}$ & $\begin{array}{l}\text { Guidelines On Taxation } \\
\text { Of Electronic } \\
\text { Commerce And The } \\
\text { Income Tax Act } 1967 \\
\text { Adanya Divisi } \\
\text { Kepatuhan Perpajakan, } \\
\text { dibawah departemen } \\
\text { kepatuhan perpajakan } \\
\text { Inland Reveneu Board } \\
\text { Malaysia. Tugas } \\
\text { utama: } \\
\text { 1. Membentuk basis } \\
\text { data bisnis e- } \\
\text { commerce } \\
\text { 2. Melakukan } \\
\text { seleksi terhadap } \\
\text { bisnis }\end{array}$ \\
\hline
\end{tabular}




\begin{tabular}{|l|l|}
\hline & \multicolumn{2}{|c|}{ commerce } \\
\hline $\begin{array}{l}\text { Penyelesaian } \\
\text { Sengketa }\end{array}$ & $\begin{array}{l}\text { Tribunal for Consumer } \\
\text { Claim }\end{array}$ \\
\hline $\begin{array}{l}\text { Pengakuan } \\
\text { Tandatangan } \\
\text { Digital }\end{array}$ & $\begin{array}{l}\text { Electronic Commerce } \\
\text { Act 2006 } \\
\text { Digital Signature Act } \\
1997\end{array}$ \\
\hline $\begin{array}{l}\text { Pengaturan } \\
\text { Lembaga } \\
\text { Sertifikasi }\end{array}$ & $\begin{array}{l}\text { Personal Data } \\
\text { Protection 2010 }\end{array}$ \\
\hline $\begin{array}{l}\text { Lembaga } \\
\text { Sertifikasi } \\
\text { Keandalan }\end{array}$ & Malaysia Trustmark \\
\hline
\end{tabular}

\section{Pengaturan E-Commerce Yang Diharapkan Yang Dapat Diterapkan Di Indonesia}

Berkaitan dengan perlindungan konsumen dalam transaksi e-commerce, suatu negara diharuskan mempunyai aturan hukum yang dapat diberlakukan secara nasional .Konsumen membutuhkan intervensi negara untuk mempengaruhi perilaku pemasok. Hal ini disebabkan konsumen tidak memiliki cukup kekuatan untuk melindunginya sendiri dalam dunia maya (J.Goldring, 2004). Penyusunan aturan hukum diharuskan mampu menyesuaikan dengan kebutuhan perkembangan jaman dan mampu menyeimbangkan kan kepentingan para pihak.

Pemerintah Indonesia saat ini tengah berusaha untuk mengembangkan praktik perdagangan elektronik agar mampu bersaing dalam dunia perdagangan internasional. Jumlah transaksi e-commerce Indonesia telah meningkat tajam walaupun masih lebih rendah dibandingkan negara-negara anggota ASEAN lainnya.

Pemerintah Indonesia melalui Kementrian Perdagangan telah membuat konsep/kerangka bagi pengaturan perdagangan berbasis elektronik. Kementrian Perdagangan mengutarakan beberapa alasan mengenai Urgensi penyusunan regulasi e-commerce di Indonesia, berikut akan diuraikan beberapa alasan:

Pertama, alasan yuridis diperlukannya undang-undang khusus yang mengatur ecommerce adalahkepastian hukum yang dijamin oleh adanya pembuatan hukum yang dilakukan secara sistematis oleh badan-badan khusus. Kedua, alasan sosiologis yaitu untuk memberikan perlindungan dan kepastian bagi para pihak yang bertransaksi secara elektronik. Ketiga, alasan filosofis karena diperlukannya ekosistem perdagangan secara elektronik yang aman dan efisien bagi semua pihak, guna mendorong bertumbuhnya konsumsi produk dalam negeri melalui transaksi secara elektronik.Keempat, penulis menambahkan alasan praktis, adanya peraturan khusus yang mengatur tentang ecommerce diharapkan mampu membuat masyarakat beradaptasi terhadap segala jenis kegiatan yang berkaitan dengan e-commerce.

Atas dasar pertimbangan diatas maka hal yang diperlukan untuk menjadikan perdagangan melalui sarana elektronik Indonesia lebih baik terutama dalam memberikan data dan/atau 
informasi yang lengkap dan benar untuk media untuk menyelesaikan sengketa yang terjadi perlindungan konsumen dalam suatu transaksi antara para pihak.

elektronik yaitu: (a) Identitas Pelaku Usaha; (b) IV. Simpulan dan Saran

pesifikasi Produk; (c) Mekanisme Pembayaran; dan (d) Mekanisme Pengiriman

Setiap sengketa bisnis yang terjadi tentunya harus diselesaikan secara cepat. Semakin banyak serta luasnya kegiatan perdagangan, maka terjadinya sengketa akan semakin tinggi sehingga mengakibatkan banyak sengketa yang harus diselesaikan.Dalam dunia bisnis saat ini, penyelesaian sengketa secara litigasi kurang efektif dan kurang disukai pelaku usaha karena menyita banyak waktu. Oleh karena itu perlu dicari suatu sistem yang tepat, efektif dan efisien. Sistem tersebut harus mempunyai kemampuan penyelesaian sengketa dengan sederhana, cepat dan biaya ringan (Mertokusumo, 2002).

Dalam dunia internasional, praktek penyelesaian sengketa e-commerce dimungkinkan untuk diselesaikan (terutama dalam sengketa bernilai kecil) dalam forum yang tepat, yang dikenal dengan istilah Online Dispute Resolution (ODR) atau Alternatif Penyelesaian Sengketa Online, yang menjadi cara praktis untuk memberikan solusi peryelesaian sengketa konsumen yang tepat, murah dan efektif (Barkatullah \& Prasetyo, 2009). ODR merupakan alternatif penyelesaian sengketa bisnis di luar pengadilan yang menggunakan internet sebagai

\section{A. Simpulan}

Berdasarkan hasil pembahasan diatas, maka dapat ditarik kesimpulan sebagai berikut:

1. Pengaturan e-commerce Indonesia dan Malaysia yaitu;

a) Pengaturan e-commerce Indonesia atau kebijakan hukum di bidang hukum ecommerce pada dasarnya telah diatur dan diakui di Indonesia, namun pengaturan tersebut masih secara parsial atau sebagian dari kegiatan e-commerce di Indonesia. Indonesia belum memiliki regulasi yang mengatur secara spesifik aturan-aturan dasar dan infrastrukturinfrastruktur teknis yang mendukung realisasi e-commerce Indonesia.

b) Pengaturan e-commerce Malaysia telah memiliki peraturan khusus mengenai ecommerce melalui Electronic Commerce Act 2006. Undang-Undang ini mengakomodir undang-undang lainnya yang mendukung pelaksanaan perdagangan elektronik, sehingga undangundang ini tidak berdiri sendiri melainkan didukung oleh beberapa Undang-undang lain sebagai pendukung, yaitu Electronic Government Activities Act 2007, Personal Data Protection Act 2010, Digital Signature 
Act 1997, dan Consumer Protection Act 1999.

2. Pengaturan e-commerce yang diharapkan dimasa yang akan datang, yaitu undangundang tentang e-commerce harus mengatur tentang kewajiban bagi pelaku usaha untuk memberikan identitasnya dengan jelas, saat mencantumkan spesifikasi produk pada halaman website harus jelas secara detil, mekanisme pembayaran jelas dan pasti untuk menghindari kesalahan pembayaran dan mekanisme pengiriman jelas cara pengiriman untuk memberikan kepastian kapan dan bagaimana barang diterima konsumen.

\section{B. Saran}

1. Diperlukan undang-undang khusus yang mengatur e-commerce.

2. Diperlukannya alternatif penyelesaian sengketa seperti yang telah berkembang di dunia Internasional yaitu Online Dispute Resolution.

\section{Daftar Pustaka}

\section{Buku}

Barkatullah, Abdul Halim., \& Prasetyo, Teguh. (2009). Bisnis E-commerce (Studi Sistem Keamanan Dan Hukum di Indonesia). Yogyakarta : Pustaka Pelajar.

Barkatullah, A.H. (2010). Sengketa Transaksi Ecommerce Internasional. Banjarmasin : FH Unlam Press
Busro, A. (2013). Kapita Selekta Hukum Perjanjian. Yogyakarta : Pohon Cahaya.

Sulaiman, Aini., Jani, Rohana., Bahri, Shamshul. (2001). The Development of E-Commerce in Malaysia. Faculty of Business and Accountancy, University of Malaya, 50603 Kuala Lumpur

Asosiasi Penyelenggara Jasa Internet Indonesia. (2016). Penetrasi Pengguna Internet Indonesia (Hasil Survey 2016)

Suhardo, E.S. (2007). Eksistensi Hak Kekayaan Intelektual Ada Realitas Duna Maya (Kapita Selekta Hukum, Menyambut Dies Natalis Fakultas Hukum UNDIP Ke 50), Semarang : Fakulatas Hukum Press.

Suparni, N. (2009). CYBERSPACE Problematika dan Antisipasi Pengaturannya. Jakart a: Sinar Grafika.

Kaligis, O.C. (2012). Penerapan Undang-undang Nomor 11 Tahun 2008 tentang Informasi dan Transaksi Elektronik Dalam Prakteknya. Jakarta : Yarsif Watampone.

Soekanto, S. (2007). Pengantar Penelitian Hukum. Jakarta : UI-Press.

Subekti. (2001). Pokok-Pokok Hukum Perdata. Jakarta : Intermasa

Mertokusumo, S. (2002). Hukum Acara Perdata Indonesia. Yogyakarta : Liberty. 


\section{Undang-undang}

UU Nomor 19 Tahun 2016 perubahan Atas UU.

No.11 tahun 2008 tentang Informasi dan Transaksi Elektronik

Undang-undang Nomor 7 Tahun 2014 tentang

Perdagangan

UU. No.11 tahun 2008 tentang Informasi dan Transaksi Elektronik

Law Of Malaysia, Electronic Government Activities Act 2007

Law Of Malaysia , Electronic Commerce Act 2006

Law Of Malaysia, Communications and Multimedia Act 1998

Law Of Malaysia, Digital Signature Act 1997

\section{Artikel J urnal , Paper dan Proceeding}

Palanissamy, A. (2013). Legal Issues in eCommerce and e-Contracting - An Overview of Initiatives in Malaysia. International Journal of e-Education, eBusiness, e-Management and e-Learning, Vol. 3 (No. 2, April 2013)

Makarim, E. (2014). Kerangka Kebijakan dan Reformasi Hukum untuk Kelancaran ECommerce. Jurnal Hukum dan Pembangunan, Vol.44 (No.3 JuliSeptember 2014)

J. Goldring. (2004). Consumer protection, the nation state, law, globalization, and democracy. Cardozo Journal of International and Comparative Law
P. Bagheri and K. H. Hassan. (2011). "Electronic Commerce, Law and Consumer Protection," in Proc. IPEDR, vol. 10,

Suparman. (2015). Urgensi Regulasi Komprehensif E-Commerce Di Indonesia Dalam Menghadapi Masyarakat Ekonomi Asean (MEA). Jurnal Mercatoria Vol 8 (No 1/) uni 2015).

\section{Hasil Wawancara}

Wawancara Direktur Jenderal Perdagangan Dalam Negeri, Kementerian Perdagangan tentang Arah Kebijakan Perdagangan Secara Elektronik (e-Commerce), Jakarta, 24 Juni 2015 